\title{
A Pharmacogenetic Approach to Blood Pressure in Lyon Hypertensive Rats A Chromosome 2 Locus Influences the Response to a Calcium Antagonist
}

\author{
Madeleine Vincent, ${ }^{\star}$ Nilesh J. Samani,‡ Dominique Gauguier, ${ }^{\S}$ John R. Thompson, ${ }^{\ddagger}$ G. Mark Lathrop, ${ }^{\S}$ and Jean Sassard* \\ *ESA Centre National de la Recherche Scientifique 5014, Département de Physiologie et de Pharmacologie Clinique, Faculté de \\ Pharmacie, Lyon 69373, France; ${ }^{\ddagger}$ Department of Cardiology, University of Leicester, Leicester LE3 9QP, United Kingdom; and \\ ${ }^{\S}$ Wellcome Trust Center for Human Genetics, University of Oxford, Oxford OX3 7BN, United Kingdom
}

\begin{abstract}
In a backcross population $(n=281)$ derived from a cross of the Lyon hypertensive rat with Lyon normotensive rat, we investigated whether genetic factors influence the acute cardiovascular responses to pharmacological modulation of the renin-angiotensin system, the sympathetic nervous system, and the voltage-sensitive L-type calcium channels. Using microsatellite markers, a quantitative trait locus was identified and mapped on rat chromosome 2 that specifically influences the systolic (peak LOD score 4.4) and diastolic (peak LOD score 4.1) blood pressure responses to administration of a dihydropyridine calcium antagonist, PY108068. The locus accounted for 10.3 and $10.4 \%$ of the total variances in the systolic and diastolic responses to PY108068 , respectively. In marked contrast, the locus had no effect on either basal blood pressure or on the responses to acute administration of a ganglionic blocking agent, trimetaphan, or of an angiotensin II subtype 1 receptor antagonist, losartan. These findings provide strong direct support for the paradigm that genetic factors may influence the response to antihypertensive drugs and suggest that the heterogeneity seen in the responses to different antihypertensive agents in human essential hypertension may have a significant genetic determination. (J. Clin. Invest. 1997. 100: 2000-2006.) Key words: blood pressure - genetics $•$ Lyon hypertensive rat $\bullet$ voltage-sensitive L-type calcium channels
\end{abstract}

\section{Introduction}

Blood pressure behaves as a quantitative trait under polygenic control in humans and in animals. Recently, molecular genetics, using either the candidate gene approach or random ge-

\footnotetext{
Address correspondence to Madeleine Vincent, Laboratoire de Physiologie, Faculté de Médecine, 8 Avenue Rockefeller, 69373 Lyon Cedex 08, France. Phone: 33-04-78-77-72-34; FAX: 33-04-78-77-71-58; E-mail: vincent@rockefeller1.univ-lyon1.fr Madeleine Vincent's current address is Laboratoire de Physiologie, Faculté de Médecine, 8 Avenue Rockefeller, 69373 Lyon Cedex 08, France.

Received for publication 27 January 1997 and accepted in revised form 22 July 1997.
}

1. Abbreviations used in this paper: F1, first filial generation; LH, Lyon hypertensive rat; LN, Lyon normotensive rat; QTL, quantitative trait locus.

J. Clin. Invest.

(C) The American Society for Clinical Investigation, Inc. 0021-9738/97/10/2000/07 \$2.00

Volume 100, Number 8, October 1997, 2000-2006

http://www.jci.org nome scanning, has allowed several loci that influence blood pressure to be identified in rat models of genetic hypertension (1-14). In addition, experimental strategies have led to the identification of loci that may specifically influence the blood pressure response to salt $(3,4,7,8,11,12)$, the temporal change in blood pressure (14), individual hemodynamic components of blood pressure (5), and the risk of end-organ damage (13). The findings have served to emphasize the pathophysiological heterogeneity of hypertension.

Heterogeneity in hypertension extends to the blood pressure response to antihypertensive medications. Several different types of drugs acting on different cardiovascular pathways are available for clinical use. These include diuretics, inhibitors of the renin-angiotensin cascade, blockers of the sympathetic nervous system, and calcium channel blockers. Although the antihypertensive efficacy of different classes of drugs is broadly similar when populations are compared, there is much individual variability in response. That part of this variability is genetic is well-documented by the resistance of some racial subgroups to particular classes of antihypertensive drugs. For example, several studies have demonstrated that compared to white subjects, black hypertensives show a much poorer response to treatment with angiotensin converting enzyme inhibitors or beta-blockers $(15,16)$. Therefore, we postulated that it may be possible to identify genetic loci that specifically influence the response to a particular class of antihypertensive agents. This study was devoted to investigate, in the Lyon model of genetic hypertension, the cosegregation of genetic loci with acute cardiovascular responses to drugs involved in the renin-angiotensin system, the sympathetic nervous system and calcium metabolism. We report the presence of a quantitative trait locus (QTL) on rat chromosome 2 that specifically influences the acute hypotensive response to a voltage-sensitive L-type calcium channel blocker (calcium antagonist).

\section{Methods}

Animal procedures. Two Lyon hypertensive (LH) males were paired with three Lyon normotensive (LN) females and two LN males with two LH females to provide the first filial generation (F1) rats. The parental LH and LN rats, which are of Sprague-Dawley origin, were obtained from generations 48-49 of our inbred colonies (17). Then 19 F1 rats were backcrossed with $19 \mathrm{LH}$ rats to obtain 281 male backcross rats. These rats, as well as 17 parental $\mathrm{LH}, 15$ parental $\mathrm{LN}$ and 37 F1 male rats, were phenotyped as described below. All animals were housed under controlled conditions of temperature $\left(21 \pm 1^{\circ} \mathrm{C}\right)$, humidity $(60 \pm 10 \%)$, and light (12-h light/dark cycle). They received a standard rat chow (UAR AO3; Usine d'Alimentation Rationnelle, Villemoisson sur Orge, Essonne, France) containing $0.3 \%$ sodium and had free access to tap water. All procedures were carried out in accordance with our institutional guidelines for animal care.

Cardiovascular parameter recordings. At 29-31 wk of age, aortic blood pressure was measured directly in freely moving rats using our computerized method $(18,19)$. Briefly, under halothane anesthesia 
( $2 \%$ in oxygen) catheters were inserted via the femoral artery into the lower abdominal aorta to recorder blood pressure and via the femoral vein into the vena cava to inject drugs. The rats were then placed in individual recording cages for a $24-\mathrm{h}$ recovery and habituation period. On the day of recording, the arterial catheter was connected to a blood pressure transducer (Spectramed DTX, Oxnard, CA) via a rotating swivel that allowed the animals to move freely. The whole recording system had been validated carefully in terms of signal dampening and resonance phenomena in the catheter. Calibration was verified before each recording.

After $90 \mathrm{~min}$ of habituation, the systolic and diastolic blood pressures were recorded beat to beat as follows: $(a)$ for $1 \mathrm{~h}$ under basal conditions; $(b)$ for $10 \mathrm{~min}$ after inhibition of the sympathetic nervous system by the short-acting ganglionic blocking agent, trimetaphan camsylate, $(10 \mathrm{mg} / \mathrm{kg}$ ) (kindly provided by Hoffman-La Roche, Basel, Switzerland); (c) for 40 min after blockade of the angiotensin II subtype 1 receptors by losartan $(20 \mathrm{mg} / \mathrm{kg}$ ) (kindly provided by DuPontMerck Pharmaceutical Co., Wilmington, DE); and (d) for $10 \mathrm{~min}$ after injection of PY108-068, a dihydropyridine calcium antagonist, $(200 \mu \mathrm{g} / \mathrm{kg}$ ) (kindly provided by Sandoz Pharma Ltd., Basel, Switzerland). The doses of the drugs and schedule of administration were chosen on the basis of pilot experiments developed in parental strains (see Fig. 1) to have the best chance to observe, within a limited period of time, the maximum effects of the three drugs. In the Lyon strains, trimetaphan and PY108-068 are both potent and have a rapid maximal effect (within $2 \mathrm{~min}$ ). While the effect of trimetaphan is shortlived, PY108-068 has a more prolonged duration of effect $(>1 \mathrm{~h})$. In contrast to these agents, the response to losartan is both much weaker (by a factor of 10) and slower in onset with a maximum effect at between 30 to $40 \mathrm{~min}$. Consequently, trimetaphan was given first. 10 min later when blood pressure had returned towards normal, the weaker and slower effects of losartan were observed over $40 \mathrm{~min}$. Finally, PY108-068 was given. As its maximum effect was seen rapidly (within $2 \mathrm{~min}$ ) it was possible to stop the readings before return to baseline blood pressure.

The average of the $\sim 20,000$ values recorded during the initial $1 \mathrm{~h}$ was taken as the basal blood pressure for each rat. The blood pressure responses to trimetaphan and PY108-068 were calculated as the difference between the average of the blood pressure values recorded for $2 \mathrm{~min}$ immediately before the drug injection and the blood pressure measured at the maximum of the response. The decrease in blood pressure induced by losartan occurred slowly and the maximum response to that drug was considered as the difference between the average of the blood pressure values recorded for $2 \mathrm{~min}$ immediately before administration and the average of the blood pressures measured during the last 2 min of the subsequent 40 min observation period. Data were analyzed in terms of both absolute responses (the actual fall in blood pressure) as well as relative responses (the fall in blood pressure/pre-drug blood pressure) to take into account the possible influence of the pre-drug blood pressure level on the responses.

Genotype determination. After isolation of high molecular weight DNA, all genotyping was done by PCR amplification of polymorphic markers. Full information on the markers and primer sequences used are available from the Wellcome Trust Centre for Human Genetics, Oxford, United Kingdom (data available on ftp://ftp.well.ox.ac.uk/ pub/genetics/ratmap) and from published maps (20, 21). PCR was performed using microtiter plates as described previously (22). The reaction volume was $15 \mu \mathrm{l}$ containing $45-\mathrm{mM}$ Tris, $\mathrm{pH} 8.8,11-\mathrm{mM}$ (NH4) ${ }_{2} \mathrm{SO}_{4}, \mathrm{pH} 8.8,1-\mathrm{mM} \mathrm{MgCl}_{2}, 6.7-\mathrm{mM} \beta$-mercaptoethanol, $4.5-\mu \mathrm{M}$ EDTA, 25- $\mu \mathrm{M}$ dNTPs, 50-ng genomic DNA, $0.25 \mu \mathrm{M}$ of each primer and $0.4 \mathrm{U}$ of Taq polymerase (Perkin-Elmer Corp., Foster City, CA). The PCR program consisted of an initial $4 \mathrm{~min}$ at $96^{\circ} \mathrm{C}$ followed by 35 cycles of $30 \mathrm{~s}$ at $94^{\circ} \mathrm{C}, 40 \mathrm{~s}$ at $55^{\circ} \mathrm{C}$ or $60^{\circ} \mathrm{C}$, and $15 \mathrm{~s}$ at $72^{\circ} \mathrm{C}$. PCR products were separated by electrophoresis on $8 \%$ polyacrylamide sequencing gels and transferred onto nylon membrane (PALL, SaintGermain en Laye, France). For each marker, the membranes were then hybridized with one of the primers radioactively labeled with $\alpha^{32} \mathrm{P}$-dCTP by terminal transferase (Boehringer Mannheim, Mann-
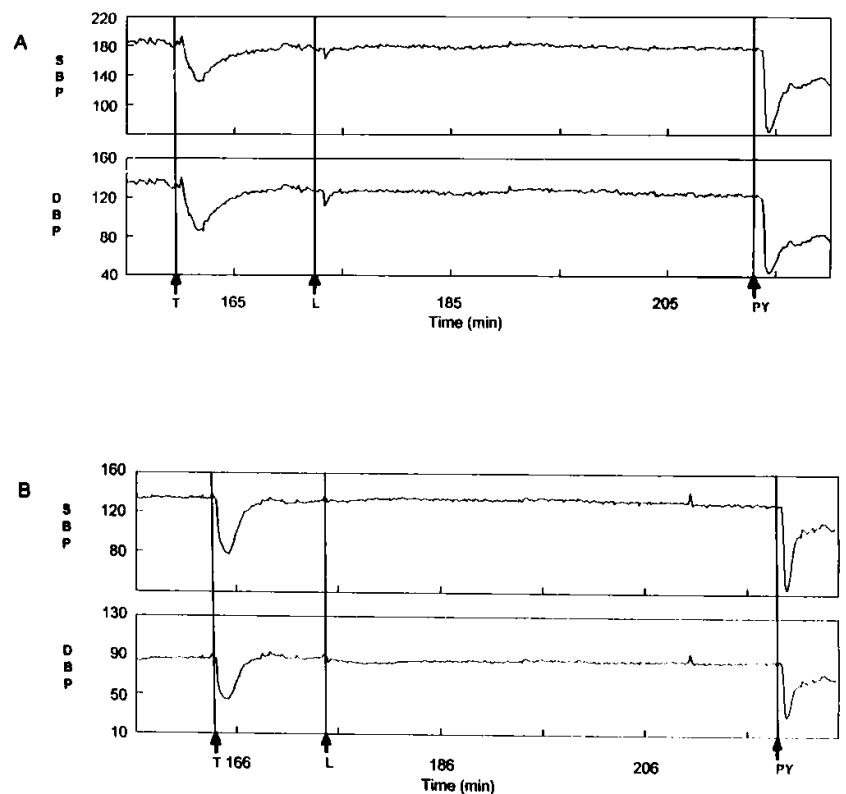

Figure 1. Typical responses of systolic $(S B P, \mathrm{mmHg})$ and diastolic $(D B P, \mathrm{mmHg})$ blood pressures, in a conscious LH $(A)$ and $\mathrm{LN}(B)$ rat, after a single injection of trimetaphan $(T)$, losartan $(L)$, and PY108-068 (PY).

heim, Germany). After washing, the membranes were exposed to autoradiography film (X-OMAT AR, Kodak) for $2-14 \mathrm{~h}$ at $-80^{\circ} \mathrm{C}$.

Statistical and linkage analysis. Data are expressed as means $\pm \mathrm{SD}$. Differences between two groups were evaluated by Student's $t$ test using the Statgraphics Plus program (Manugistics Inc., Rockville, MD). Linkage map and QTL localization were done with the MAPMAKER programs $(23,24)$ kindly provided by Dr. Lander (Whitehead Institute, Cambridge, MA).

\section{Results}

Phenotypic traits in parental rats. Under basal conditions, LH rats had significantly higher systolic and diastolic blood pressures compared with LN rats (Table I). After acute administration of losartan, changes in systolic and diastolic pressures were small and not different between the two strains. Trimetaphan induced marked decreases in systolic and diastolic blood pressures in both $\mathrm{LH}$ and LN parental strains and the change in diastolic blood pressure was significantly greater in LH than in LN rats. Finally, PY108-068 administration was followed by decreases in systolic and diastolic blood pressures which were significantly greater in both absolute (Table I) and relative (systolic: $-58.1 \pm 5.7 \%$ versus $-46.5 \pm 11.3 \%, P=0.001$ ); diastolic: $-60.8 \pm 4.9 \%$ versus $-46.4 \pm 13.4 \%, P=0.0004$ ) terms in $\mathrm{LH}$ than in $\mathrm{LN}$ rats.

Phenotypic traits in F1 and backcross rats. The distribution of values for individual traits in $\mathrm{F} 1$ animals showed a variable pattern with the mean for some traits lying at the midparental value while that for other traits closer to the $\mathrm{LN}$ values (Table I). In the backcross rats, all the traits were normally distributed (data not shown). The correlation between the responses to the various drugs was poor $(r<0.144$ in all cases).

Mapping of QTL on chromosome 2 influencing blood pressure response to PY108-068. As part of a whole genome search 


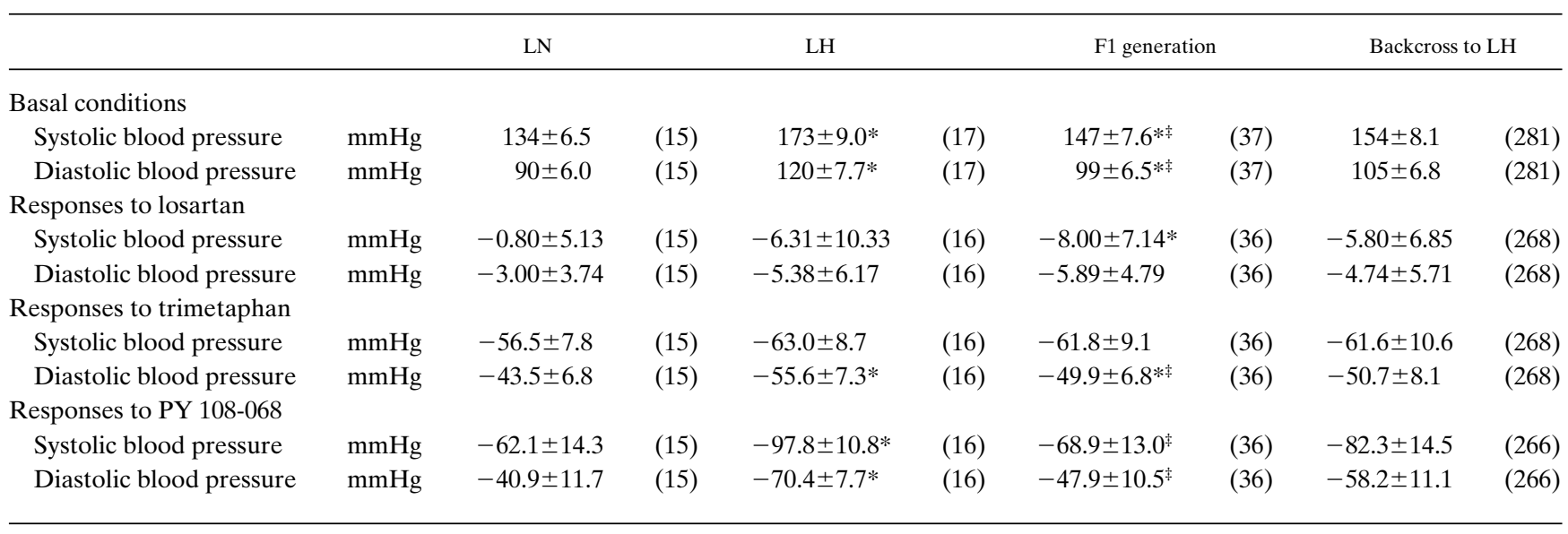

Values are expressed as means \pm SD. ${ }^{*} P<0.05$ versus $\mathrm{LN} ;{ }^{\ddagger} P<0.05$ versus $\mathrm{LH}$.

(see Discussion), markers on several chromosomes were analyzed (see Methods). An interim analysis suggested that the presence of a locus on chromosome 2 influencing the blood pressure response to the dihydropyridine calcium antagonist PY108-068. Additional markers on chromosome 2 were then identified from published maps and analyzed for polymorphism between LH and LN rats. Backcross animals were genotyped for all informative markers. Table II shows the markers analyzed and the linkage map derived from the genotype data.

The response of systolic and diastolic blood pressure to PY108-068 in backcross animals grouped by genotype for each marker analyzed on chromosome 2 is shown in Table III. For 8 out of 11 markers tested, the fall in blood pressure was significantly greater in animals homozygous for the LH allele compared with those that were heterozygous. Fig. 2 shows the QTL LOD plots for systolic and diastolic response to PY108068 derived from this data using MAPMAKER-QTL. For both systolic and diastolic responses, the peak effect was localized between markers D2Wox8 and D2Mit 15. The maximum

Table II. Markers Analyzed on Chromosome 2 and the Linkage Map Derived from the Genotype Data

\begin{tabular}{clllr}
\hline Marker & Marker name & Locus name & & $\begin{array}{c}\text { Distance } \\
\text { (cM) }\end{array}$ \\
\hline 1 & D2Wox15 & $C p b$ & (Carboxypeptidase B) & 57.6 \\
2 & D2Wox19 & $P k l$ & (Pyruvate-kinase L) & 8.8 \\
3 & D2Wox20 & $P k l$ & (Pyruvate-kinase L) & 1.7 \\
4 & D2Wox26 & Nkaalb & (Na+/K+ ATPase $\alpha 1)$ & 2.4 \\
5 & D2Mit14 & & & 2.1 \\
6 & D2Wox27 & Ox44 & (Leukocyte antigen & \\
& & & MRC Ox44) & 5.7 \\
7 & D2Mgh12 & & & 2.7 \\
8 & D2Wox8 & & & 35.7 \\
9 & D2Mit15 & & & 18.2 \\
10 & D2Mit16 & & &
\end{tabular}

D2Wox2 is at the top of the chromosome and could not be placed on the map (93 cM away from D2Wox15). Marker names are those assigned by Lathrop et al. (ftp://ftp.well.ox.ac.uk./pub/genetics/ratmap) (Wox) or Jacob et al. (21) (Mit/Mgh).
LOD scores for the systolic and diastolic responses were 4.4 and 4.1, respectively. The QTL accounted for 10.3 and $10.4 \%$ of the total variances in the absolute systolic and diastolic responses to PY108-068 respectively in the backcross population. Results were essentially similar but slightly weaker when the responses were analyzed in relative terms with maximum LOD scores of 3.0 and 2.7 for systolic and diastolic blood pressures, respectively.

In contrast to the effect found for blood pressure response to PY108-068, no effect was seen on basal systolic or diastolic blood pressure (Fig. 2), apart from a modest effect on diastolic blood pressure at marker D2Wox15 (HH 107 \pm 7 versus HN $104 \pm 6, P=0.002)$. Likewise, no association was detected between any of the chromosome 2 markers and the systolic or the diastolic blood pressure responses to acute administration of the other drugs studied, trimetaphan or losartan (Table III).

\section{Discussion}

The findings in this study indicate the presence of a QTL on rat chromosome 2 specifically affecting the acute blood pressure responses to blockade of the voltage-dependent L-type calcium channels. As far as we are aware, this is the first demonstration of a QTL influencing the blood pressure response to a specific pharmacological agent. The specificity of this QTL for the responses to blockade of L-type calcium channel in our cross is strongly supported by the absence of significant linkage between the QTL and either basal blood pressure or the blood pressure responses to losartan and trimetaphan that lower blood pressure through other pathways. The presence of distinct genetic factors influencing the response to the different classes of drugs is in addition suggested by the absent or weak correlations between the blood pressure responses to the three agents in backcross rats and by different patterns of distribution of blood pressure responses to trimetaphan and PY108-068 in F1 generation rats (Table I).

Recent studies have shown that dissection of complex quantitative traits such as blood pressure (3-14) or glucose homeostasis $(22,25)$ regulation into subphenotypes may provide important tools in the resolution of genetic heterogeneity of conditions such as hypertension and non-insulin-dependent diabetes mellitus. In this study, dissection of blood pressure 


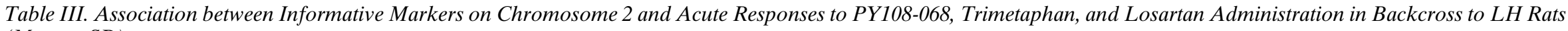
(Means $\pm S D$ )

\begin{tabular}{|c|c|c|c|c|c|c|c|c|c|c|c|c|c|c|c|c|c|c|c|c|c|c|}
\hline \multirow[b]{3}{*}{ Marker } & \multirow[b]{3}{*}{ Gene } & \multicolumn{7}{|c|}{ Responses to PY108-068 administration ( $\mathrm{mmHg}$ ) } & \multicolumn{7}{|c|}{ Responses to trimetaphan administration (mmHg) } & \multicolumn{7}{|c|}{ Responses to losartan administration $(\mathrm{mmHg})$} \\
\hline & & \multicolumn{4}{|c|}{$\begin{array}{l}\text { Systolic blood } \\
\text { pressure }\end{array}$} & \multicolumn{3}{|c|}{$\begin{array}{l}\text { Diastolic blood } \\
\text { pressure }\end{array}$} & \multirow[b]{2}{*}{$n$} & \multicolumn{3}{|c|}{$\begin{array}{l}\text { Systolic blood } \\
\text { pressure }\end{array}$} & \multicolumn{3}{|c|}{$\begin{array}{l}\text { Diastolic blood } \\
\text { pressure }\end{array}$} & & \multicolumn{3}{|c|}{$\begin{array}{l}\text { Systolic blood } \\
\text { pressure }\end{array}$} & \multicolumn{3}{|c|}{$\begin{array}{l}\text { Diastolic blood } \\
\text { pressure }\end{array}$} \\
\hline & & $n$ & $\mathrm{NH}$ & $\mathrm{HH}$ & $P$ & NH & $\mathrm{HH}$ & $P$ & & $\mathrm{NH}$ & $\mathrm{HH}$ & $P$ & $\mathrm{NH}$ & $\mathrm{HH}$ & $P$ & & NH & $\mathrm{HH}$ & $P$ & NH & $\mathrm{HH}$ & $P$ \\
\hline D2Wox 2 & & 262 & $\begin{array}{l}-81.7 \\
\pm 14.2\end{array}$ & $\begin{array}{l}-83.5 \\
\pm 14.7\end{array}$ & NS & $\begin{array}{l}-58.0 \\
\pm 11.4\end{array}$ & $\begin{array}{l}-59.1 \\
\pm 10.8\end{array}$ & NS & 262 & $\begin{array}{l}-60.8 \\
\pm 10.9\end{array}$ & $\begin{array}{l}-61.9 \\
\pm 10.1\end{array}$ & NS & $\begin{array}{r}-50.3 \\
\pm 8.5\end{array}$ & $\begin{array}{r}-50.8 \\
\pm 7.7\end{array}$ & NS & 262 & $\begin{array}{l}-5.35 \\
\pm 7.52\end{array}$ & $\begin{array}{l}-5.98 \\
\pm 6.25\end{array}$ & NS & $\begin{array}{l}-3.84 \\
\pm 6.00\end{array}$ & $\begin{array}{l}-5.04 \\
\pm 5.38\end{array}$ & NS \\
\hline D2Wox15 & $C p b$ & 273 & $\begin{array}{l}-80.8 \\
\pm 13.2\end{array}$ & $\begin{array}{l}-84.3 \\
\pm 15.9\end{array}$ & 0.058 & $\begin{array}{l}-56.8 \\
\pm 10.3\end{array}$ & $\begin{array}{l}-60.1 \\
\pm 11.7\end{array}$ & 0.017 & 273 & $\begin{array}{l}-62.2 \\
\pm 10.0\end{array}$ & $\begin{array}{l}-60.6 \\
\pm 11.3\end{array}$ & NS & $\begin{array}{r}-50.8 \\
\pm 7.8\end{array}$ & $\begin{array}{r}-50.6 \\
\pm 8.7\end{array}$ & NS & 273 & $\begin{array}{l}-5.31 \\
\pm 6.91\end{array}$ & $\begin{array}{l}-6.48 \\
\pm 6.70\end{array}$ & NS & $\begin{array}{l}-4.67 \\
\pm 5.56\end{array}$ & $\begin{array}{l}-5.03 \\
\pm 5.76\end{array}$ & NS \\
\hline D2Wox19 & $P k l$ & 217 & $\begin{array}{l}-79.8 \\
\pm 13.1\end{array}$ & $\begin{array}{l}-86.3 \\
\pm 14.9\end{array}$ & 0.0008 & $\begin{array}{l}-56.5 \\
\pm 10.2\end{array}$ & $\begin{array}{l}-61.2 \\
\pm 11.3\end{array}$ & 0.001 & 219 & $\begin{array}{l}-62.0 \\
\pm 10.7\end{array}$ & $\begin{array}{l}-60.6 \\
\pm 11.0\end{array}$ & NS & $\begin{array}{r}-50.9 \\
\pm 7.9\end{array}$ & $\begin{array}{r}-50.5 \\
\pm 8.4\end{array}$ & NS & 219 & $\begin{array}{l}-6.24 \\
\pm 6.26\end{array}$ & $\begin{array}{l}-5.69 \\
\pm 7.01\end{array}$ & NS & $\begin{array}{l}-5.16 \\
\pm 5.73\end{array}$ & $\begin{array}{l}-4.18 \\
\pm 5.71\end{array}$ & NS \\
\hline D2Wow20 & $P k l$ & 225 & $\begin{array}{l}-78.4 \\
\pm 12.4\end{array}$ & $\begin{array}{l}-86.4 \\
\pm 15.4\end{array}$ & 0.00006 & $\begin{array}{l}-55.9 \\
\pm 10.3\end{array}$ & $\begin{array}{l}-61.3 \\
\pm 11.8\end{array}$ & 0.0006 & 225 & $\begin{array}{r}-61.8 \\
\pm 9.2\end{array}$ & $\begin{array}{l}-60.6 \\
\pm 10.5\end{array}$ & NS & $\begin{array}{r}-50.5 \\
\pm 7.3\end{array}$ & $\begin{array}{r}-50.5 \\
\pm 8.3\end{array}$ & NS & 225 & $\begin{array}{l}-5.94 \\
\pm 6.91\end{array}$ & $\begin{array}{l}-5.02 \\
\pm 7.11\end{array}$ & NS & $\begin{array}{l}-4.73 \\
\pm 5.50\end{array}$ & $\begin{array}{l}-3.82 \\
\pm 5.90\end{array}$ & NS \\
\hline D2Wox26 & Nkaalb & 281 & $\begin{array}{l}-79.2 \\
\pm 12.5\end{array}$ & $\begin{array}{l}-85.6 \\
\pm 15.6\end{array}$ & 0.0004 & $\begin{array}{l}-56.2 \\
\pm 10.0\end{array}$ & $\begin{array}{l}-60.6 \\
\pm 11.6\end{array}$ & 0.001 & 281 & $\begin{array}{l}-62.2 \\
\pm 10.0\end{array}$ & $\begin{array}{l}-61.1 \\
\pm 11.3\end{array}$ & NS & $\begin{array}{r}-50.6 \\
\pm 7.6\end{array}$ & $\begin{array}{r}-50.9 \\
\pm 8.7\end{array}$ & NS & 281 & $\begin{array}{l}-6.05 \\
\pm 6.81\end{array}$ & $\begin{array}{l}-5.52 \\
\pm 7.04\end{array}$ & NS & $\begin{array}{l}-5.03 \\
\pm 5.67\end{array}$ & $\begin{array}{l}-4.29 \\
\pm 5.82\end{array}$ & NS \\
\hline D2Mit14 & & 193 & $\begin{array}{l}-79.4 \\
\pm 12.5\end{array}$ & $\begin{array}{l}-86.4 \\
\pm 15.0\end{array}$ & 0.00062 & $\begin{array}{l}-56.9 \\
\pm 10.3\end{array}$ & $\begin{array}{l}-61.7 \\
\pm 11.4\end{array}$ & 0.0025 & 195 & $\begin{array}{l}-61.4 \\
\pm 10.3\end{array}$ & $\begin{array}{l}-60.0 \\
\pm 10.7\end{array}$ & NS & $\begin{array}{r}-49.7 \\
\pm 7.8\end{array}$ & $\begin{array}{r}-50.3 \\
\pm 8.5\end{array}$ & NS & 195 & $\begin{array}{l}-6.29 \\
\pm 6.71\end{array}$ & $\begin{array}{l}-6.03 \\
\pm 6.49\end{array}$ & NS & $\begin{array}{l}-4.62 \\
\pm 5.50\end{array}$ & $\begin{array}{l}-4.03 \\
\pm 5.82\end{array}$ & NS \\
\hline D2Wox 27 & $O x 44$ & 174 & $\begin{array}{l}-79.5 \\
\pm 12.7\end{array}$ & $\begin{array}{l}-88.0 \\
\pm 14.6\end{array}$ & 0.00009 & $\begin{array}{r}-57.6 \\
\pm 9.9\end{array}$ & $\begin{array}{l}-63.3 \\
\pm 11.3\end{array}$ & 0.0007 & 174 & $\begin{array}{r}-59.9 \\
\pm 9.0\end{array}$ & $\begin{array}{l}-59.3 \\
\pm 10.7\end{array}$ & NS & $\begin{array}{r}-49.2 \\
\pm 7.1\end{array}$ & $\begin{array}{r}-49.7 \\
\pm 8.6\end{array}$ & NS & 174 & $\begin{array}{l}-6.76 \\
\pm 5.84\end{array}$ & $\begin{array}{l}-6.62 \\
\pm 6.42\end{array}$ & NS & $\begin{array}{l}-4.33 \\
\pm 5.03\end{array}$ & $\begin{array}{l}-4.31 \\
\pm 5.75\end{array}$ & NS \\
\hline D2Mgh12 & & 196 & $\begin{array}{l}-79.3 \\
\pm 12.6\end{array}$ & $\begin{array}{l}-86.8 \\
\pm 15.0\end{array}$ & 0.00018 & $\begin{array}{l}-56.5 \\
\pm 10.0\end{array}$ & $\begin{array}{l}-62.0 \\
\pm 11.5\end{array}$ & 0.00046 & 198 & $\begin{array}{r}-60.2 \\
\pm 9.6\end{array}$ & $\begin{array}{l}-61.2 \\
\pm 11.4\end{array}$ & NS & $\begin{array}{r}-49.0 \\
\pm 7.8\end{array}$ & $\begin{array}{r}-51.5 \\
\pm 8.5\end{array}$ & NS & 198 & $\begin{array}{l}-6.12 \\
\pm 6.39\end{array}$ & $\begin{array}{l}-5.85 \\
\pm 6.96\end{array}$ & NS & $\begin{array}{l}-4.60 \\
\pm 5.51\end{array}$ & $\begin{array}{l}-4.08 \\
\pm 5.82\end{array}$ & NS \\
\hline D2Wox8 & & 249 & $\begin{array}{l}-78.3 \\
\pm 12.4\end{array}$ & $\begin{array}{l}-86.5 \\
\pm 15.3\end{array}$ & 0.000006 & $\begin{array}{r}-55.5 \\
\pm 9.8\end{array}$ & $\begin{array}{l}-61.3 \\
\pm 11.8\end{array}$ & 0.000033 & 251 & $\begin{array}{l}-61.3 \\
\pm 10.3\end{array}$ & $\begin{array}{l}-61.4 \\
\pm 10.5\end{array}$ & NS & $\begin{array}{r}-49.9 \\
\pm 7.9\end{array}$ & $\begin{array}{r}-51.2 \\
\pm 8.1\end{array}$ & NS & 251 & $\begin{array}{l}-6.10 \\
\pm 6.81\end{array}$ & $\begin{array}{l}-5.33 \\
\pm 7.08\end{array}$ & NS & $\begin{array}{l}-4.94 \\
\pm 5.68\end{array}$ & $\begin{array}{l}-4.16 \\
\pm 5.80\end{array}$ & NS \\
\hline D2Mit15 & & 237 & $\begin{array}{l}-80.0 \\
\pm 14.0\end{array}$ & $\begin{array}{l}-84.8 \\
\pm 14.0\end{array}$ & 0.0091 & $\begin{array}{l}-56.1 \\
\pm 10.5\end{array}$ & $\begin{array}{l}-60.4 \\
\pm 11.1\end{array}$ & 0.0025 & 239 & $\begin{array}{l}-61.1 \\
\pm 12.0\end{array}$ & $\begin{array}{c}-61.5 \\
\pm 9.2\end{array}$ & NS & $\begin{array}{r}-49.7 \\
\pm 9.1\end{array}$ & $\begin{array}{r}-51.2 \\
\pm 7.2\end{array}$ & NS & 239 & $\begin{array}{l}-5.87 \\
\pm 6.42\end{array}$ & $\begin{array}{l}-5.64 \\
\pm 7.47\end{array}$ & NS & $\begin{array}{l}-5.10 \\
\pm 5.43\end{array}$ & $\begin{array}{l}-4.03 \\
\pm 6.12\end{array}$ & NS \\
\hline D2Mit16 & & 195 & $\begin{array}{l}-81.3 \\
\pm 14.4\end{array}$ & $\begin{array}{l}-84.6 \\
\pm 14.1\end{array}$ & NS & $\begin{array}{l}-58.2 \\
\pm 11.0\end{array}$ & $\begin{array}{l}-60.6 \\
\pm 11.2\end{array}$ & NS & 196 & $\begin{array}{l}-59.2 \\
\pm 11.4\end{array}$ & $\begin{array}{c}-60.8 \\
\pm 8.8\end{array}$ & NS & $\begin{array}{r}-48.6 \\
\pm 9.1\end{array}$ & $\begin{array}{r}-50.6 \\
\pm 7.2\end{array}$ & NS & 196 & $\begin{array}{l}-6.09 \\
\pm 5.32\end{array}$ & $\begin{array}{l}-6.12 \\
\pm 7.53\end{array}$ & NS & $\begin{array}{l}-4.35 \\
\pm 5.15\end{array}$ & $\begin{array}{l}-4.18 \\
\pm 6.13\end{array}$ & NS \\
\hline
\end{tabular}




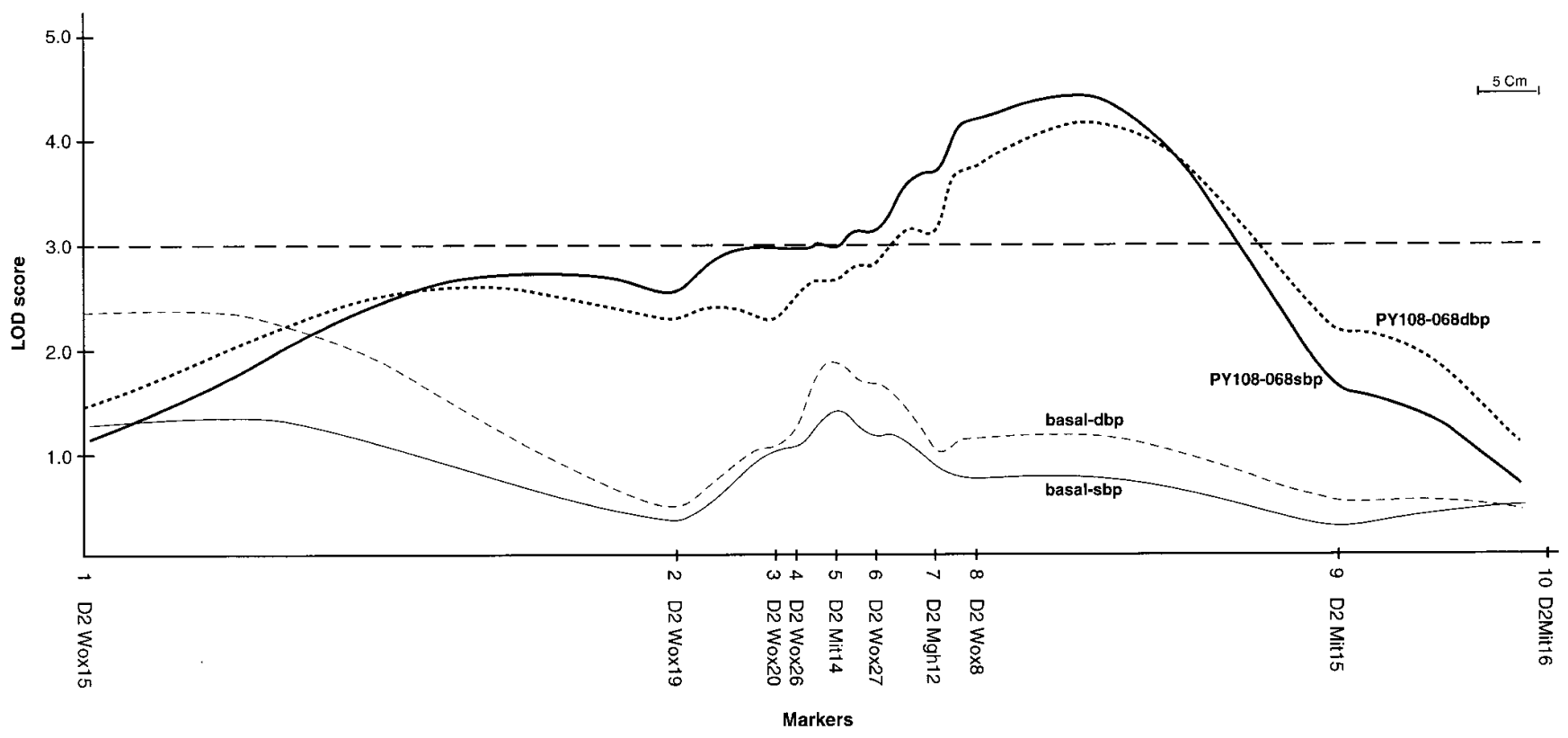

Figure 2. QTL LOD plots for markers on chromosome 2 and systolic $(s b p)$ and diastolic $(\mathrm{dbp})$ blood pressures under basal conditions and after acute PY108-068 administration. The horizontal dotted line indicates a LOD score of 3.0. See Table II for list of markers and locus names.

into additional subphenotypes using a pharmacological approach has been useful in identifying a QTL which may be specifically involved in calcium metabolism-related blood pressure regulation.

Considerable evidence exists that calcium plays a central role in the regulation of vascular smooth muscle contraction and there is growing evidence in human and animal studies that alterations of calcium metabolism at either the systemic or cellular level may be involved in the pathogenesis of hypertension (26-29). Moreover, similar alterations in calcium metabolism have been found in the normotensive offspring of hypertensive parents suggesting that they may be genetically determined (30). Of more direct relevance to the findings here, high calcium diet and parathyroidectomy in LH rats influence blood pressure and vascular reactivity $(31,32)$. In addition, $\mathrm{LH}$ rats exhibited alterations in cell calcium handling in platelets and erythrocytes (33) and an exaggerated renal vasoconstrictive response to an L-type calcium channel opener (BAY k 8644) (34). Taken together, these findings suggest the presence of a genetically determined abnormality in calcium metabolism that could be associated with high blood pressure in the LH rat. The finding, therefore, of a QTL that specifically influences the acute blood pressure responses to blockade of the voltage-dependent calcium channel is consistent with this hypothesis.

Previous studies have identified two regions containing QTLs influencing blood pressure phenotypes on rat chromosome 2. A region around the angiotensin II subtype $1 \mathrm{~B}$ receptor $(A t 1 b r) /$ carboxypeptidase B $(C p b)$ genes was found to contain a QTL that influenced pulse pressure in $\mathrm{F} 2$ rats derived from an LH $\times$ LN cross (5) and a QTL that influenced blood pressure on high salt diet in crosses involving the Dahl S rat (7). This region is some distance away from the region containing the QTL influencing the response to PY108-068 found in this study (Fig. 2). However, the region mapped here overlaps largely with a region containing another QTL that influences blood pressure responses on high salt diet in Dahl rats (7) and a region containing a QTL that influences basal systolic and diastolic blood pressure on normal salt diet in a cross of the spontaneously hypertensive rat (SHR) with the Wistar-Kyoto rat (14). Whether the different effects seen in the different crosses reflect varying manifestations of the same gene or the influence of separate genes cannot be established from the available data. The fact that we did not find a significant effect on basal blood pressure potentially suggests that the response to PY108-068 represents the effect of a distinct gene. Only the ultimate identification of a causative gene through various approaches including the construction of congenic lines and the testing of candidate gene(s) will allow this question to be answered. In this context, it is notable that the gene for a major protein involved in intracellular calcium homeostasis, calmodulin-dependent protein kinase II-delta (Camk), lies on chromosome $2(7,35)$ precisely in the interval between D2Wox8 and D2Mit15 containing the peak effect we observed. Therefore, this gene clearly represents an important candidate gene deserving further investigation.

For both systolic and diastolic blood pressures, the difference between $\mathrm{HN}$ and $\mathrm{HH}$ rats observed for the marker with the maximal effect (D2Wox8) was between $20-25 \%$ of the difference seen in the corresponding responses between the parental strains (Tables I and III). Since we studied backcross animals and therefore only compared animals homozygote for the hypertensive allele with heterozygotes, it is possible that the influence of the locus could be double that seen, if the locus acted in a codominant rather than recessive fashion. Nevertheless, this finding suggests the presence of other loci that influence the response to calcium channel blockade that remain to be identified. Likewise, whether distinct loci exist that specifically influence the response to the other agents tested also remains to be determined. A genome-wide scan is ham- 
pered to some extent in the Lyon strains because of similarities between the two strains (because of the manner of their derivation) resulting in a low polymorphism index (5). At this time, we have tested 40 other microsatellite markers scattered across several chromosomes (1, 3, 4, 6-10, 12-14, 16, 18 and X) and not found another locus significantly influencing the response to the pharmacological agents studied (data not shown).

Our protocol has several limitations including the serial use of drugs over a short space which means that any persistent influences of an agent, interactions between agents, or the effect of any counter-regulatory mechanism cannot be fully excluded. Specifically, blood pressure could not return to basal values between losartan and PY108-068 (Fig. 1). However, since the effect of losartan was of a much smaller magnitude compared to that of PY108-068, it is very unlikely to have affected the findings with PY108-068. More importantly, it is necessary to recognize that we only studied acute responses to intravenously administered boluses whose (genetic) regulation may be different compared with the responses to chronic oral dosing of the same class of agents. Nonetheless, our findings provide strong direct support for the paradigm that genetic factors may influence the response to antihypertensive agents and suggest that a further search for QTLs affecting responses to such agents in both experimental models and man may provide information that is ultimately of clinical benefit in the management of a very common and chronic disorder.

In summary, these data strongly point to the existence of a QTL on rat chromosome 2 specifically affecting calcium-related blood pressure regulation. Moreover, the fact that this locus did not influence blood pressure responses induced by pharmacological maneuvers on two other major systems involved in blood pressure homeostasis, suggests that the analogous heterogeneity in the responses to antihypertensive therapy in human essential hypertension may have a genetic determination.

\section{Acknowledgments}

We thank G. Hadour for her help, and P. Privat and V. Orea for their technical assistance.

This work was supported by grants from Institut National de la Santé et de la Recherche Médicale (INSERM/MSD, grant number 92 AN 25), from the Wellcome Trust, and from the British Heart Foundation and by the EURHYPGEN programme of the Commission of the European Communities.

\section{References}

1. Rapp, J.R., S.M. Wang, and H. Dene. 1989. A genetic polymorphism in the renin gene of Dahl rats cosegregates with blood pressure. Science (Wash. DC). 243:542-544.

2. Kurtz, T.W., L. Simonet, P.M. Kabra, S. Wolfe, L. Chan, and B.L. Hjelle. 1990. Cosegregation of the renin allele of the spontaneously hypertensive rat with an increase in blood pressure. J. Clin. Invest. 85:1328-1332.

3. Hilbert, P., K. Lindpaintner, J.S. Beckmann, T. Serikawa, F. Soubrier, C. Dubay, P. Cartwright, B. de Gouyon, D. Julier, S. Takahasi, et al. 1991. Chromosomal mapping of two genetic loci associated with blood pressure regulation in heredity hypertensive rats. Nature (Lond.). 353:521-529.

4. Jacob, H.J., K. Lindpaintner, S.E. Lincoln, K. Kusumi, R.K. Bunker, Y. Mao, D. Ganten, V. Dzau, and E.S. Lander. 1991. Genetic mapping of a gene causing hypertension in the stroke-prone spontaneously hypertensive rat. Cell. 67:213-224.

5. Dubay, C., M. Vincent, N.J. Samani, P. Hilbert, M.A. Kaiser, J.P. Beressi, Y. Kotelevtsev, J.S. Beckmann, F. Soubrier, J. Sassard, and G.M. Lathrop. 1993. Genetic determinants of diastolic and pulse pressure map to different loci in Lyon hypertensive rats. Nat. Genet. 3:354-357.
6. Samani, N.J., D. Lodwick, M. Vincent, C. Dubay, M.A. Kaiser, M.P. Kelly, M. Lo, J. Harris, J. Sassard, G.M. Lathrop, and J.D. Swales. 1993. A gene differentially expressed in the kidney of the spontaneously hypertensive rat cosegregates with increased blood pressure. J. Clin. Invest. 92:1099-1103.

7. Deng, A.Y., H. Dene, and J.P. Rapp. 1994. Mapping of a quantitative trait locus for blood pressure on rat chromosome 2. J. Clin. Invest. 94:431-436.

8. Deng, A.Y., H. Dene, M. Pravenec, and J.P. Rapp. 1994. Genetic mapping of two new blood pressure quantitative trait loci in the rat by genotyping endothelin system genes. J. Clin. Invest. 93:2701-2709.

9. Lodwick, D., M.A. Kaiser, J. Harris, F. Cumin, M. Vincent, and N.J. Samani. 1995. Analysis of the role of angiotensinogen in spontaneous hypertension. Hypertension (Dallas). 25:1245-1251.

10. Pravenec, M., D. Gauguier, J.-J. Schott, J. Buard, V. Kren, C. Bila, C. Szpirer, J. Szpirer, J.-M. Wang, H. Huang, et al. 1995. Mapping of quantitative trait loci for blood pressure and cardiac mass in the rat by genome scanning of recombinant inbred strains. J. Clin. Invest. 96:1973-1978.

11. Gu, L., H. Dene, A.Y. Deng, B. Hoebee, M.T. Bihoreau, M. James, and J.P. Rapp. 1996. Genetic mapping of two blood pressure quantitative trait loci on rat chromosome 1. J. Clin. Invest. 97:777-788.

12. Clark, J.S., B. Jeffs, A.O. Davidson, W.K. Lee, N.H. Anderson, M.-T. Bihoreau, M.J. Brosnan, A.M. Devlin, A.W. Kelman, K. Lindpaintner, and A.F. Dominiczak. 1996. Quantitative trait loci in genetically hypertensive rats. Possible sex specificity. Hypertension (Dallas). 28:898-906.

13. Rubattu, S., M. Volpe, R. Kreutz, U. Ganten, D. Ganten, and K. Lindpaintner. 1996. Chromosomal mapping of quantitative trait loci contributing to stroke in a rat model of complex human disease. Nat. Genet. 13:429-434.

14. Samani, N.J., D. Gauguier, M. Vincent, M.A. Kaiser, M.T. Bihoreau, D. Lodwick, R. Wallis, V. Parent, P. Kimber, F. Rattray, et al. 1996. Analysis of quantitative trait loci for blood pressure on rat chromosome 2 and 13: agerelated differences in effect. Hypertension (Dallas). 28:1118-1122.

15. Saunders, E., M.R. Weir, W. Kong, J. Hollified, J. Gray, V. Vertes, J.R. Sowers, M.B. Zemel, C. Curry, J. Schoenberger, et al. 1990. A comparison of the efficacy and safety of a beta-blocker, a calcium channel blocker and a converting enzyme inhibitor in hypertensive blacks. Arch. Intern. Med. 150:17071713 .

16. Materson, B.J., D.J. Reda, W.C. Cushman, B.M. Massie, E.D. Freis, M.S. Kochar, R.J. Hamburger, C. Fye, R. Lakshman, J. Gottdiener, et al. 1993. Single-drug therapy for hypertension in men. A comparison of six antihypertensive agents with placebo. N. Engl. J. Med. 328:914-921.

17. Vincent, M., J. Sacquet, and J. Sassard. 1984. The Lyon strain of hypertensive, normotensive and low blood pressure rats. In Handbook of Hypertension. Experimental and Genetic Models of Hypertension. W. de Jong, editor. Elsevier Science B.V., Amsterdam. 314-327.

18. Su, D.F., C. Cerutti, C. Barrès, M. Vincent, and J. Sassard. 1986. Blood pressure and baroreflex sensitivity in conscious hypertensive rats of the Lyon strain. Am. J. Physiol. 251:H1111-H1117.

19. Gustin, M.P., C. Cerutti, and C.Z. Paultre. 1990. Heterogeneous computer network for real-time hemodynamic signals processing. Comput. Biol. Med. 20:205-215.

20. Serikawa, T., T. Kuramoto, P. Hilbert, M. Mori, J. Yamada, C.J. Dubay, K. Lindpaintner, D. Ganten, J.L. Guenet, G.M. Lathrop, and J.S. Beckmann. 1992. Rat gene mapping using PCR-analyzed microsatellites. Genetics. 131:701-721.

21. Jacob, H.J., D.M. Brown, R.K. Bunker, M.J. Daly, V.J. Dzau, A. Goodman, G. Koike, V. Kren, T.W. Kurtz, A. Lemmark, et al. 1995. A genetic linkage map of the laboratory rat, Rattus norvegicus. Nat. Genet. 9:63-69.

22. Gauguier, D., P. Froguel, V. Parent, C. Bernard, M.T. Bihoreau, B. Portha, M.R. James, L. Penicaud, G.M. Lathrop, and A. Ktorza. 1996. Chromosomal mapping of genetic loci associated with non-insulin dependent diabetes in the GK rat. Nat. Genet. 12:38-43.

23. Lander, E.S., P. Green, J. Abrahamson, A. Barlow, M.J. Daly, S.E. Lincoln, and L. Newburg. 1987. MAPMAKER: an interactive computer package for constructing primary genetic linkage maps of experimental and natural populations. Genomics. 1:174-181.

24. Lander, E., and D. Bostein. 1989. Mapping mendelian factors underlying quantitative traits using RFLP linkage maps. Genetics. 12:185-199.

25. Galli, J., L.S. Li, A. Glaser, C.G. Ostenson, H. Jiao, H. Fakhrai-Rad, H.J. Jacob, E.S. Lander, and H. Luthman. 1996. Genetic analysis of non-insulin dependent diabetes mellitus in the GK rat. Nat. Genet. 12:31-37.

26. Hermsmeyer, K., and P. Erne. 1995. Vascular muscle ion channels and cellular calcium regulation in hypertension. In Hypertension: Pathophysiology, Diagnosis and Management, Second Edition. J.H. Laragh and B.M. Brenner, editors. Raven Press, Ltd., New York. 673-683.

27. Hatton, D.C., E.W. Young, R.D. Bukoski, and D.A. McCarron. 1995. Calcium metabolism in experimental genetic hypertension. In Hypertension Pathophysiology, Diagnosis and Management, Second Edition. J.H. Laragh and B.M. Brenner, editors. Raven Press, Ltd., New York. 1193-1211.

28. Orlov, S.N., N.I. Pokudin, and Y.V. Postnov. 1988. Calcium transport in erythrocytes of rats with spontaneous hypertension. J. Hypertens. 6:829-837.

29. Lindner, A., T.R. Hinds, R.C. Davidson, and F.F. Vincenzi. 1993. Increased cytosolic free calcium in red blood cells is associated with essential hypertension in humans. Am. J. Hypertens. 6:771-779.

30. Van Hooft, I.M.S., D.E. Grobbee, M. Frolich, H.A.P. Pols, and A. Hof- 
man. 1993. Alterations in calcium metabolism in young people at risk for primary hypertension. The Dutch hypertension and offspring study. Hypertension (Dallas). 21:267-272.

31. Pernot, F., R. Schleiffer, C. Bergmann, M. Vincent, J. Sassard, and A. Gairard. 1990. Dietary calcium, vascular reactivity, and genetic hypertension in the Lyon strain. Am. J. Hypertens. 3:846-853.

32. Pernot, F., R. Schleiffer, M. Vincent, J. Sassard, and A. Gairard. 1990. Parathyroidectomy in the Lyon hypertensive rat: cardiovascular reactivity and aortic responsiveness. J. Hypertens. 11:1111-1117.
33. Zicha, J., M.G. Pernollet, J. Kunes, B. Lacour, M. Vincent, J. Sassard, and M.A. Devynck. 1995. Alterations of cytosolic calcium in platelets and erythrocytes of Lyon hypertensive rats. Am. J. Hypertens. 8:842-849.

34. Medeiros, I.A., B.L. Zhang, S. Bertolino, and J. Sassard. 1994. Pressure control of renal renin release in Lyon hypertensive rats. J. Hypertens. 12:871-877.

35. Zha, H., R.L. Wilder, E.A. Goldmuntz, J.M. Cash, L.J. Crofford, P. Mathern, and E.F. Remmers. 1993. Linkage map of 10 polymorphic markers on rat chromosome 2. Cytogenet. Cell Genet. 63:117-122. 